\title{
Shock and Law: Fin 48 Report Card, IFRS, and Beyond
}

\author{
Namryoung Lee (Corresponding author) \\ Professor of Accounting, Korea Aerospace University \\ 200-1, Hwajeon-dong, Deokyang-gu, Goyang-city, Gyeonggi-do, Korea, 412-791 \\ Tel: 822-300-0093Ｅ-mail: nrlee@kau.ac.kr \\ Charles Swenson \\ Professor and Leventhal Research Fellow, Marshall School of Business \\ University of Southern California, 3660 Trousdale PKWY \\ University of Southern California, Los Angeles, CA 90089
}

Tel: 1-213-740-4854 E-mail: cswenson@marshall.usc.edu

The authors acknowledge the helpful comments of Lillian Mills, Cristi Gleason, Richard Sansing, K.R. Subramanyam, Tatiana Sandino, Bob Trezevant, Rebecca Hann, Nerissa Brown, and participants the Accounting Research Forum at USC.

\begin{abstract}
The accounting for income taxes has, and will continue to, undergo significant changes. FASB Interpretation (FIN) 48 significantly revised the financial accounting for income taxes in 2007 . In our sample, $87 \%$ of firms were immediately affected in terms of a restatement of beginning 2007 retained earnings. After enactment, discretionary accruals significantly decreased as firms apparently did not find other methods (other than through income tax accounts) to manage earnings. On the other hand, FIN 48 appears to have caused disruption in the reporting standards for income taxes, insofar as an increase in variability in effective tax rates across firms both the year before adoption, and the year of adoption. International Financial Reporting Standards (IFRS) will also make significant changes in 2012. We comment on the likely effects of IFRS adoption on US firms. Then, we examine the less volatile effects of IFRS on effective tax rates for European companies after 2004 as an example of what might happen in the US.
\end{abstract}

Keywords: Accounting for Income Taxes, FIN 48, IFRS

\section{Introduction}

One of the most celebrated recent changes in accounting standards was FASB Interpretation (FIN) 48, which significantly revised the financial statement accounting for income taxes. Effective for firm years beginning after December 15, 2006 (i.e, initially affecting calendar year end firms on their 2007 financials), FIN 48 revises the accounting for income taxes under Financial Accounting Standard (SFAS) 109. In essence, FIN 48 requires firms to assess the likelihood of government acceptance of each tax position that the firm takes, assign estimated values to such position, and to disclose any significant contentious tax position in the tax note of the financial statements.

Additionally, any cumulative differences in applying FIN 48, versus pre-FIN 48 accounting, was to be accounted for as a restatement of the firm's beginning retained earnings for 2007. These FIN 48 adjustments can be measured in such retained earnings restatements. Such adjustments should be positive for firms who had used "reserve" accounts composed of potential future taxes, to manage or "smooth" earnings, as they would disgorge reserves used for such purposes. As noted by Chester S. Spatt, Chief Economist and Director of the Office of Economic Analysis, U.S. Securities and Exchange Commission:

"By limiting discretion in the setting of tax reserves the FIN 48 standard can potentially reduce under-estimation of reserves and also limit the flexibility of management. Managerial flexibility in accounting can be of concern in a variety of settings because it can potentially lead to "cookie jar" accounting in which managerial discretion masks the firm's performance information and smoothes its earnings profile." (Note 1)

The FIN 48 retained earnings adjustment could be both positive and negative; firms who used tax accounts to manage earnings might have a positive adjustment, while a negative adjustment would be expected due to the FIN 48 more restrictive standard to recognize tax savings strategies. The "more likely than not" requirement standards (under FAS 109) (Note 2) to recognize a tax saving strategy is thought to be more restrictive than previous; accordingly, application of FIN 48 should increase tax expense. Additionally, firms would need to 
make negative adjustments to beginning 2007 retained earnings for tax positions which did not pass the increased scrutiny of FIN 48. Such an adjustment is thought to be a signal to the Internal Revenue Service (IRS) that the firm is aggressive and may be a good target for a tax audit. Similarly, tax aggressiveness post-FIN 48 would eventually be disclosed in the 2007 10Q, since FIN 48 requires all significant tax positions be disclosed. This post-FIN 48 disclosure requirement was also thought to decrease firms' appetites for tax aggressive positions.(Note 3) Alternatively, such disclosure may cause firms to more vigorously defend their tax positions to auditors so that no signal-emitting financial statement adjustment occurs. Additionally, if firms were de facto applying a more likely than not standard prior to FIN 48, we would expect FIN 48 adjustments simply as a function of differences in accounting.

Given the significant amount of resources allocated to FIN 48 compliance, by both firms and their auditors, it is important to know whether FIN 48 has had any measurable impact on firms' accounting for income taxes, and as a collateral effect, on tax aggressiveness.(Note 4) This study focuses solely on whether FIN 48 had an immediate financial statement impact in 2007, whether the firms intended to be affected by FIN 48 actually were affected, and whether firms made preemptive responses to such disclosures in 2006.

Our research shows that FIN 48 has a significant impact in terms of firms restating their beginning 2007 retained earnings to reflect cumulative (pre-2007) adjustments in deferred taxes. Firms which were prone to smooth earnings showed a significant impact in terms of a retained earnings increase; such firms had kept tax reserves in a deferred asset account, to be released slowly to meet earnings requirements, were now effectively required to disgorge such amounts as a retroactive restatement of retained earnings. In general, firms significantly decreased their beginning retained earnings to reflect aggressive tax positions which could not hold up to the "more likely than not" test of FIN 48. After the implementation of FIN 48, we find that firms significantly decreased their discretionary accruals, indicating that they did not find other (non-tax) accounts with which to manage earnings. Perhaps most importantly, we find that FIN 48 cause a surge in the variability of firms effective tax rates, before the year before adoption, and the year of adoption. Since managers and analysts use effective tax rates as performance benchmarks, such variability may have been harmful.

Because the accounting for income taxes will change again in 2012 when International Financial Reporting Standards (IFRS) is mandated for publicly-traded firms, it is also worth looking forward to the potential impact of this new standard. We do a comparison of US GAAP versus IFRS reporting for income taxes. Next, we examine what might happen in the U.S. by looking at the EU experience after it mandated IFRS in 2005 . We find that post IFRS, the variability of effective tax rates decreased significantly, implying that reporting became more standardized across firms.

\section{Accounting for income taxes under FIN 48}

Firms are required to account for income taxes under FAS 109. Under this method, differences between tax expense for book purposes, and actual taxes paid on tax returns, are accounted for on a balance sheet method. Here reserves are set up for taxes which may be paid (or benefits which may be realized) in the future. As tax positions become clearer, reserves are released to increase or decrease tax expense as well as income for financial reporting purposes.

The decision on when to release reserves is subject to the firm's judgment under FAS 109, and previous research (see discussion in the next section) has found that firms release reserves to meet earnings targets (typically set by outside financial analysts). FIN 48 was enacted to mitigate the use of the tax accounts for earnings management, as well as providing a more restrictive test of when to recognize the benefits of tax strategies. While keeping the general framework of FAS 109, FIN 48 requires more fine judgment as to reserve creation and related earnings releases. Central to the FIN 48 quantification is the requirement that a firm examine each tax position and first determine whether it is "more likely than not" to be upheld upon government scrutiny. If not meeting this test, tax benefits would not be recognized for financial reporting purposes. If a firm does meet this test, then the predicted tax benefit is estimated by looking at tax benefits associated with outcomes above a certain likelihood.

Firms were required to retroactively comply with FIN 48 for all pre-FIN 48 tax reserves. Any such FIN 48 adjustments were to be accounted for "as if" it were an error correction, with a corresponding restatement for the cumulative adjustment to beginning 2007 retained earnings. In addition to being required to use FIN 48 going forward, firms were also required to disclose, in the tax note, any significant controversial tax positions, starting with the 2007 10K.

Figure 1 presents a FIN 48 overview in comparison to before FIN 48 issuance.

\section{[Insert Figure 1 about here]}




\subsection{FIN 48 Studies}

Two descriptive studies are worthy of note. Nicholas, Briggs, and Baril (2007) examine the disclosures provided on adoption of FIN 48 by calendar year-end Fortune 200 companies in their March 31, 2007, Forms 10-Q and find that the adoption of FIN 48 resulted in substantial changes in the measurement of unrecognized tax benefits for many firms. Dunbar, Kolbasovsky, and Phillips (2007) analyze the first quarter 2007 10-Q filings of 348 S\&P 500 calendar year-end firms to tax find that the largest firms in their sample displayed the most conservative tax reporting behavior, and that such behavior varied by auditor.

Song and Tucker (2008) using a sample of 273 industrial firms find that profitable high-reserve firms both reduced their reserve levels and significantly increased their leverage from 2005 to 2007, suggesting tax-sheltering activities being displaced by more debt utilization prior to the mandatory FIN 48 reporting. Blouin, Gleason, Mills, and Sikes (2008) examine hand-collected disclosures for 200 non-financial, non-utility firms followed by analysts from 2005 through 2007, find that firms are more likely to decrease reserves in the quarters prior to adopting FIN 48 if they have excess reserves at FIN 48 enactment. Mills, Robinson, and Sansing (2008) develop a model which demonstrates that the economic effects of FIN 48 include: higher expected payoffs to some taxpayers that claim uncertain tax benefits; a disclosed liability that may understate the expected tax liability; and continued claims of uncertain tax benefits by taxpayers whose circumstances only weakly support their position.

\section{Impact of FIN 48-Retroactive effect of FIN 48: adjustments to retained earnings}

In general, we predict that firms will show a negative retained earnings adjustment to FIN 48, as the more stringent "more likely than not" standard, applied retroactively, would reduce prior years' tax savings and increase tax liability. This negative adjustment should be larger for firms which are tax aggressive, where larger, contentious tax positions may not stand up to the "more likely than not" test of FIN 48. The other big driver of the negative adjustment is the inability to consider the probability of audit and detection. For small and midsize firms, this change is likely to significantly increase their need for reserves after FIN 48 (see findings in Blouin et al. 2008).

The data consist of annual Compustat Global and North America financial data from 2001 to 2007. To make sure the sample only contained firms who would be affected in the first quarter of 2007, only calendar year firms are included Of the 2,605 usable observations for the first quarter of $2007,87 \%$ had restatements of beginning retained earnings, $52 \%$ of which reported a negative adjustment. Twenty-three per cent (23\%) had adjustment greater than $\$ 1$ million (either positive or negative). This is a significant percent of the sample and, consistent with Blouin et al. (2008), demonstrates that FIN 48 had a broad impact across firms. Descriptive statistics appear in the table below.

\section{[Insert Table 1 about here]}

Table 2 shows descriptive statistics for firm characteristics.(Note 5) Although these univariate statistics are consistent with the predictions in Figure 2, pair-wise $t$ tests of differences between means are not significant due to large standard deviations.

\section{[Insert Table 2 about here]}

We take a more rigorous approach by building a regression model which tests whether the FIN 48 adjustment was a function of prior tax aggressiveness and earnings management. To the extent firms were overly tax aggressive and the risky tax positions were not fully reflected in prior reserves(Note 6). we would expect FIN 48 would require a negative retained earnings adjustment to reflect a more realistic reserve for taxes. To the extent that firms used the tax reserves as a cushion to mange or smooth earnings, we would expect a positive adjustment to retained earnings (Note 7).

The basic model is (predicted sign in parentheses):

$$
\begin{array}{cccc}
{\text { FIN } 48 A D J_{i}=}^{\alpha_{0}+\alpha_{1} \text { TAGG }_{i}} & +\alpha_{2} \text { SMOOTHER }_{i}+\alpha_{3} \text { TAGG }^{*} \text { SMOOTHER }_{i}+\alpha_{4} \text { ROA }+\varepsilon_{i} \\
(-) & (-) & (+) & (- \text { or }+)
\end{array}
$$

where:

FIN48ADJ $=\$$ restatement of beginning 2007 retained earnings, manually taken from firms' 2007

Form 10-Q for the first quarter of 2007. This amount is then divided by lagged total

assets, to control for size effects across firms; 
$T A G G$

$=$ tax aggressiveness, where $\mathrm{TAGG}=1$ if 1 - cash effective tax rate is greater than the sample median, and 0 otherwise, as determined over prior 6 years;

SMOOTHER = degree to which firm uses discretionary accruals, where SMOOTHER=1 if (the

absolute value of) discretionary accruals are greater than the sample median, and 0

otherwise, as determined over prior 6 year, and

ROA $=$ return on assets.

To estimate DACC(discretionary accruals), we use the Jones model, modified by Dechow et al.(1995)(Note 8):

$$
T A_{i t}=\beta_{0}+\beta_{1} / A S S E T S_{i t-1}+\beta_{2} \Delta\left(S A L E S_{i t}-A R_{i t}\right)+\beta_{3} P P E_{i t}+\varepsilon_{i t}
$$

where:

$T A_{i t} \quad=$ the total accruals in fiscal year $\mathrm{t}$ obtained by subtracting operating cash flows from

net income before extraordinary items and discontinued operations, deflated by the

beginning-of-year total assets;

$\operatorname{ASSETS}_{i t-1} \quad=$ the total assets at the beginning of fiscal year $\mathrm{t}$;

$\Delta\left(S A L E S_{i t}-A R_{i t}\right) \quad=$ the change in sales, adjusted for the change in accounts receivable from fiscal years $\mathrm{t}-1$ to $\mathrm{t}$, deflated by the beginning-of-year total assets, and

$P P E_{i t} \quad=$ the gross property, plant and equipment at the end of fiscal year $\mathrm{t}$, deflated by the beginning-of-year total assets.(Note 9)

We estimate discretionary accruals (DA) using both the Dechow et al. (1995) and Kothari et al. (2005) methods. We split the analysis into firms which had Big 4 auditors, and others. Prior research suggests that firms having Big 4 auditors may have tighter control on both the firm's ability to manage earnings through accruals, and also act as a deterrent to overly aggressive tax avoidance. Table 3 reports results for firms with Big 4 auditors. The general intercept is negative and significant, capturing the general effect on all firms of retroactively applying the "more likely than not" requirements under FIN 48. However, there appears to be no effect if the firm was classified as either an earnings manager, or tax aggressive.

\section{[Insert Table 3 about here]}

Table 4 shows a very different result for firms not having Big 4 auditors. Firms who are classified as earnings managers report a significant positive adjustment to beginning retained earnings. Firms which were tax aggressive but not earnings managers had negative adjustments (Note 10), and firms who were both earnings managers AND tax aggressive experienced negative retained earnings adjustments due to FIN 48.

\section{[Insert Table 4 about here]}

\subsection{Did FIN 48 Affect discretionary accruals?}

The table below shows discretionary accruals, where the dependent variable is the standardized residual (absolute value) from the modified Jones model. Both the Dechow et al. (1995) and Kothari et al. (2005) models are used. FIN 48 would appear to be effective if discretionary accruals decreased post implementation. As shown in the table, firms in fact did dramatically reduce discretionary accruals in 2007; the difference between the 2006 (0.015 lower than the omitted year of 2001) and 2007 (0.023 lower than the omitted year of 2001) is significant $(\mathrm{t}=42.67)$ (Note 11). Apparently, such firms were unable to find other accounts (substituting for tax reserves) to manage earnings after the effective implementation date of FIN 48.

\section{[Insert Table 5 about here]}

\subsection{Did FIN 48 "Tighten up" the accounting for income taxes?}

If FIN 48 increased standardization of reporting for income taxes, then we would expect to see less variability across firms after its implementation. The following table shows that although discretionary accruals decreased, the variation in effective tax rates (using financial accounting rules) increased both the year prior to adoption (as firms made anticipatory changes) and also in the year of adoption itself. Pre-FIN 48 ETRs had an average variance of $4.37 \%$, while 2006 and 2007 ETR variances were $15.1 \%$ and approximately 10\%, on average.

\section{[Insert Table 6 about here]}

\section{IFRS}

Starting in 2012, publicly traded firms will have to switch to International Financial Reporting Standards. Under IFRS, the accounting for income taxes will be different than the current FIN 48. 


\subsection{What will be the Big Changes to Income Tax Accounting under IFRS?}

Adopting IFRS involves a fundamental change in the framework of how U.S. companies measure pre-tax income and the principles governing accounting for income taxes. Companies' tax liabilities may change simply because the numbers on the balance sheet or the income statement change. In other cases, IFRS may change the amount of deferred tax recognized in financial statements.

To start, there are a significant number of potential differences between IFRS and U.S. GAAP which could materially affect pre-tax accounting income. Examples of such differences include the accounting for revenue, leases, asset impairments, classification and measurement of financial instruments, hedging activity and stock-based compensation, to name a few.

In the U.S., tax methods of accounting do not necessarily follow the "book" method of accounting. As a result, a conversion to IFRS will require an analysis of each new accounting policy for its related tax implications, including a determination as to whether it is permissible or advisable to conform the related tax method of accounting to the new book accounting method. It is important to remember that a tax accounting method does not automatically change because the book accounting method changes. Rather, the consent of the IRS Commissioner must be obtained to change an accounting method for U.S. tax purposes.

\subsection{Major Tax Issues}

\section{Cash Taxes}

The move to IFRS could have a significant impact on both U.S. and foreign cash taxes of a company. In most jurisdictions, financial reporting is often the starting point in determining taxable income for tax filing purposes. As financial accounting policies change from existing GAAP to IFRS, companies will need to consider the implications of such changes on cash taxes.

\section{LIFO vs. FIFO}

IFRS also is a major tax issue for companies using the LIFO method to value inventories. IFRS does not permit the use of LIFO, and the tax law does not permit the use of LIFO unless the method is used for financial reporting purposes. Unless this LIFO conformity requirement is changed through legislation, U.S. companies currently using LIFO will face a tax cost with a change to IFRS for financial reporting. Under current law, the effect of the change from LIFO to FIFO (known as the $\S 481$ (a) adjustment) may be spread over four years, though Congress is considering repealing the LIFO method and allowing a longer spread period. Unless there is new legislation, U.S. companies now using LIFO will face a tax cost with a change to IFRS for financial reporting.

\section{Fair-Value Measurement}

Under IFRS companies can elect to measure property, plant equipment, and investment property at fair value, and certain financial instruments may be required to be carried at fair value. These measurement concepts could have a significant impact on debt-to-equity and other balance sheet ratios, potentially resulting in limitations on interest deductibility for tax purposes.

\section{Uncertain Tax Positions}

The International Accounting Standards Board currently does not intend to adopt a standard similar to Federal Accounting Standard No. 48. Under IFRS "a liability for tax uncertainties is based on the amount of taxes expected to be paid to the tax authorities," and the FIN 48 two-step process for recognition and measurement is not specified. IFRS currently has nothing like FIN 48. The International Accounting Standards Board is working on revisions that would add a FIN 48-like requirement, but it would probably require companies to book such prospective liabilities only to the extent they deem them certain — which is a lesser standard than FIN 48 under GAAP.

Other major differences between US GAAP and IFRS reporting for taxes are shown in Table 7.

\section{[Insert Table 7 about here]}

\section{The EU Experience}

Will this switch cause large swings in tax rates, and increased variability in earnings? Suggestive results can be obtained by looking at the EU's experience in switching to IFRS in 2005. We examined the effective tax rates (ETRs) for all EU firms listed on Global Compustat. We look at the three years before IFRS (2002 through 2004) and compare them to 2005 through 2007. Results for pre-IFRS ETRs are shown in Table 8a; Table 8b reports post IFRS data. As can be seen, there is little change in average ETRs reported before versus after IFRS. 
However, there is a significant reduction in the variance in ETRs after IFRS. This variance drops from $2.69 \%$ to $1.79 \%$, a result consistent with a tightening up, or standardization, in the accounting for income taxes.

\section{[Insert Tables 8a and 8b about here]}

While the results suggest that variability in ETRs was reduced after IFRS, it is important to note that this is not an entirely analogous situation to the forthcoming US change in 2012. Prior to IFRS, EU companies used a wide variety of reporting standards. In contrast, at the time of the US switch in 2012 US firms will all be using the current FAS 109/FIN 48 reporting standards. However, the results are highly suggestive. Although EU firms had lower variability in ETRs than the US both before and after IFRS, the overall reduction in variance for EU countries post IFRS - a 34\% reduction-is stunning, and suggests that US firms may experience reduced variability in their ETRs.

\section{Conclusion}

Our study shows that FIN 48 had a significant impact in terms of firms restating their beginning 2007 retained earnings to reflect cumulative (pre-2007) adjustments in deferred taxes. Firms which were prone to manage earnings showed a significant impact in terms of a retained earnings increase. Here, firms which had kept tax reserves in a deferred asset account, to be released slowly to meet earnings requirements, were effectively required to disgorge such amounts as a retroactive restatement of retained earnings. Firms which were prone to tax aggressiveness significantly decreased their beginning retained earnings, to reflect aggressive tax positions which could not hold up to the scrutiny of FIN 48.

After the implementation of FIN 48, we find that firms significantly decreased their discretionary accruals, indicating that they did not find other (non-tax) accounts with which to manage earnings. However, firms experience a significant increase in variability in effective tax rates after FIN 48, suggesting that interpretation of the standard is not uniform across firms.

The effects of FIN 48 will be relatively short-lived, however, as IFRS will replace FIN 48 in 2012. Upon examination of IFRS principles, it is likely that there will be significant changes in 2012. Examining the EU experience of switching to IFRS, we see that there was relatively little effect on effective tax rates on average. However, the variance in ETRs decreased markedly after adoption, suggesting that IFRS tightened up the accounting for income taxes, and may have the same stabilizing effects on US ETRs.

\section{References}

AICPA. (2006). Practice guide on accounting for uncertain tax positions under FIN 48.

Badertscher B., J. Phillips, M. Pincus, and S. Rego. (2006). Do Firms Manage Earnings Downward in a Book-Tax Conforming Manner? Working Paper, University of Connecticut, University of California - Irvine, and University of Iowa.

Badertscher, B., J. Phillips, M. Pincus, and S. Rego. (2006) Tax implications of earnings management activities: Evidence from restatements. Working paper, University of Connecticut, University of California - Irvine, and University of Iowa.

Blouin J., C. Gleason, L. Mills, and S. Sikes, (2008) Do Firms Eat their Tax Cookies before FIN 48 Reveals the Cookie Jar? Working paper, The Wharton School-University of Pennsylvania, University of Iowa, and McCombs School of Business-University of Texas.

Blouin J., C. Gleason, L. Mills, and S. Sikes. (2008). Changes in Tax Reserves in Anticipation of FIN 48(*An earlier version of this paper was titled, "Do Firms Eat their Tax Cookies before FIN 48 Reveals the Cookie Jar?") Working paper, The Wharton School-University of Pennsylvania, University of Iowa, and McCombs School of Business-University of Texas.

Blouin J., C. Gleason, L. Mills and S. Sikes. (2008). What can we learn about uncertain tax benefits from FIN 48 ? National Tax Journal.

Dechow, P., R. Sloan and A. Sweeney. (1995). Detecting earnings management. The Accounting Review 70 (2): 193-225.

Dhaliwal, D., C. Gleason and L. Mills. (2004). Last chance earnings management: using the tax expense to meet analysts' forecasts. Contemporary Accounting Research 21 (2): 431-457.

Dunbar, A., L. Kolbasovsky and J. Phillips. (2007). FIN 48 adoption disclosures. Financial Reporting Watch, Forthcoming.

Frank, M., L. Lynch and S. Rego. (2006). Does Aggressive Financial Reporting Accompany Aggressive Tax Reporting (and Vice Versa)? Working paper, University of Virginia and University of Iowa. 
FASB, (2006). FASB Interpretation No. 48. Accounting for uncertainty in income taxes.

FASB. 1992. Statement of Financial Accounting of Standards No. 109. Accounting for Income Taxes.

Gleason C. and L. Mills, (2002). Materiality and contingent tax liability reporting. The Accounting Review 77(2): 317-342.

Kothari, S. P., A. Leone, and C. Wasley, (2005). Performance matched discretionary accruals. Journal of Accounting and Economics 39 (1): 161-197.

Mills, L., L. Robinson, and R. Sansing, (2008). FIN 48 and tax compliance. Working paper, University of Texas at Austin and Tuck School of Business at Dartmouth.

Nicholas, N., J. Briggs, and C. Baril, (2007). And the impact is ... First-quarter results from adoption FIN 48. Tax Notes, Vol. 116, No. 5.

Phillips, J., M. Pincus, and S. Rego, (2003). Earnings management: new evidence based on deferred tax expense. The Accounting Review 78(2): 491-521.

Song, W. and A. Tucker, (2008). Corporate tax reserves, firm value, and leverage. Working paper, Louisiana State University and Pace University - Lubin School of Business.

\section{Notes}

Note 1. Speech, March 7, 2007.

Note 2. In addition to the more stringent requirement that the position would be expected to be upheld on an audit, without litigation.

Note3. Ex-post the actual disclosures in turns out that the 2007 10Ks did not show much of this detail. Mills et al. (2008) examined 200 firms and found that disclosures are by major jurisdiction and details are only present for disputed amounts after the audit.

Note 4. An equally - if not more important - question is the degree to which FIN 48 resulted in firms meaningfully disclosing any controversial tax positions on their note. See and which discuss the importance of this in terms of tax signaling to the IRS and the potential resultant on audit scrutiny. See discussions of this in Blouin et al. (2008) and Mills, Robinson, and Sansing (2008).

Note 5. The sample used for this univariate comparison is the same as used for the subsequent regression results. For the regression results shown in Table 3, some firms were eliminated because of incomplete data, reducing the sample from 2,584 to 1,924 .

Note 6. Frank, Lynch, and Rego (2006) find that aggressive financial reporting is associated with aggressive tax strategies. Using tax return data, Gleason and L. Mills (2002) find that firms fail to disclose IRS claims for tax deficiencies that exceed a 5-percent-of-income rule of thumb, consistent with firms using a stable measure of size, such as assets or normal income, to gauge materiality, rather than relying only on current period reported income. Badertscher, Phillips, Pincus, and Rego (2006) find that nonconforming earnings management is more prevalent than conforming earnings management, and that firms trade off the net present value of tax benefits against the net expected detection costs associated with nonconforming earnings management.

Note 7. See Phillips, Pincus, and Rego (2003) and Dhaliwal, Gleason, and L. Mills (2004) who show that firms use the tax provision and related reserves to manage earnings.

Note 8. We also estimated "discretionary accruals" using Jones Model modified by Kothari et al. (2005) as a measure of earnings management including a performance measure in the accruals regression:

TAit $=\beta 0+\beta 1 /$ ASSETSit- $1+\beta 2 \Delta($ SALESit-AR $)+\beta 3$ PPEit $+\beta 4$ ROAit $+\varepsilon$ it

where: ROAit $=$ net income divided by lagged total assets of fiscal year $\mathrm{t}$.

Note 9. The COMPUSTAT variables are: Total Accrual $=($ Data18-Data308)/lag(Data6),

where: Assetsi,t-1 = Data6 at the beginning of fiscal year t;

$\Delta($ SALESit-AR $) \quad=($ Data12-lag(Data12) $) / \operatorname{lag}($ Data6 $)-($ Data302-lag $($ Data302) $) / \operatorname{lag}($ Data6 $)$, and

PPEit $\quad=$ Data7/lag(Data6)

Note 10. We also used "book-tax difference" as a measure of tax aggressiveness, but the results were similar.

Note 11. Regression results for only calendar year-end firms are essential identical, as follows:

2006 dummy: $-0.02(-5.61)^{* *} ; 2007$ dummy: $-0.03(-8.55)^{* *}$ (** significant at the 0.01 level)

$\mathrm{T}$ tests of coefficient equivalence: 2005 versus $2006(\mathrm{t}=12.82) ; 2006$ versus $2007(\mathrm{t}=55.56)$. 
Table 1. Descriptive Statistics: Opening Balance Restatement of Retained Earnings at the Adoption of FIN 48 (Amounts in \$ Millions)

\begin{tabular}{|c||c|}
\hline \multicolumn{1}{|c||}{ Total Firms } & $\mathbf{2 , 6 0 5}$ \\
\hline No. Firms with Positive Change & $\begin{array}{c}911(35 \%) \\
\text { with change }>\text { \$1 million) }\end{array}$ \\
\hline No. Firms with No change & $347(13 \%)$ \\
\hline No. Firms with Negative Change & $1,346(52 \%)$ \\
\hline Mean & $(412$ firms with change $>$ - $\$$ million) \\
\hline Median & 0.33 \\
\hline Std. Deviation & 0.00 \\
\hline Minimum (firm name) & 52.21 \\
\hline Maximum (firm name) & -654.00 (Qwest Communication Int'l Inc.) \\
\hline
\end{tabular}

Table 2. Firm Characteristics: Descriptive Statistics For FIN 48 Retained Earnings Restatements (in \$ Millions; sample size $=1,920$ )

\begin{tabular}{|c||c|c|c|c|}
\hline $\begin{array}{c}\text { Group } \\
\text { (predicted sign in parentheses) }\end{array}$ & Mean & Std. Deviation & ROA(mean) & Auditors (\%) \\
\hline \hline $\begin{array}{c}\text { Not Earnings Manager, Not Tax Aggressive (-) } \\
\text { (432 firms) }\end{array}$ & -0.71 & 33.61 & 0.11 & Big 4: 368(85.2) \\
\hline $\begin{array}{c}\text { Earnings Manager, Not Tax Aggressive (+) } \\
\text { (709 firms) }\end{array}$ & 0.39 & 40.53 & 0.13 & Non-Big 4: 64(14.8) \\
\hline $\begin{array}{c}\text { Not Earnings Manager, Tax Aggressive (-) } \\
\text { (391 firms) }\end{array}$ & -2.14 & 34.27 & -0.15 & Non-Big 4: $120(16.9)$ \\
\hline $\begin{array}{c}\text { Earnings Manager and Tax Aggressive (?) } \\
\text { (388 firms) }\end{array}$ & -3.86 & 38.63 & -0.06 & Non-Big 4: $102(26.9)$ \\
\hline
\end{tabular}

Table 3. Regression Results-FIN 48 Adjustment to Beginning 2007 Retained Earnings: Firms with Big Four Auditors

Model:

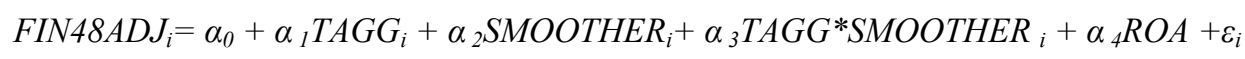

DA Estimated Using the method of Dechow et al. (1995)

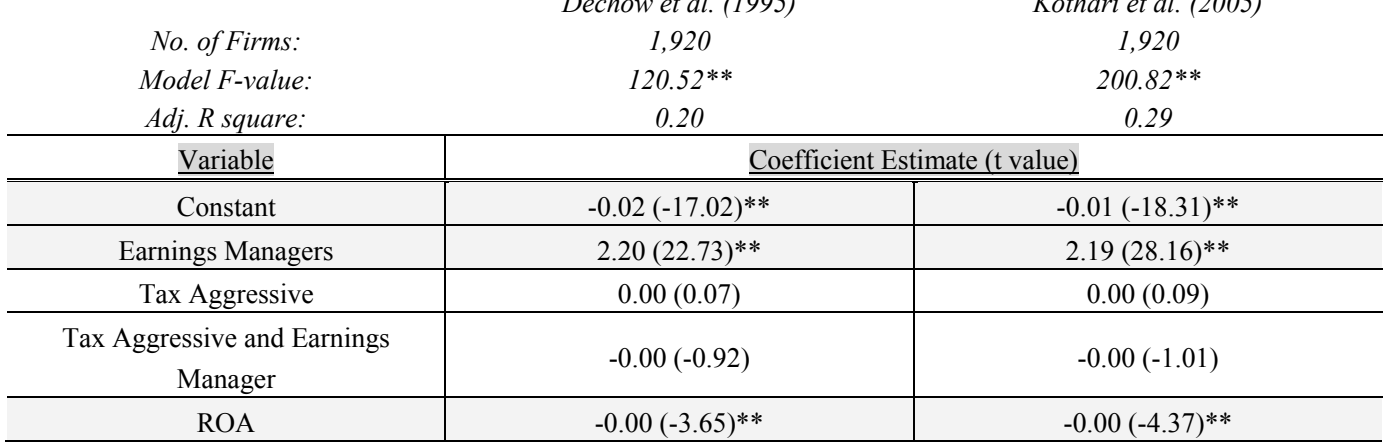

** significant at the 0.01 level

Notes: FIN48ADJ $=\$$ restatement of beginning 2007 retained earnings, manually taken from firms' 2007

Form 10-Q for the first quarter of 2007. This amount is then divided by lagged total assets, to control for size effects across firms;

$T A G G=$ tax aggressiveness, where $\mathrm{TAGG}=1$ if 1 - cash effective tax rate is greater than the sample median, and 0 otherwise, as determined over prior 6 years;

SMOOTHER = degree to which firm uses discretionary accruals, where SMOOTHER=1 if (the absolute value of) discretionary accruals are greater than the sample median, and 0 , otherwise, as determined over prior 6 years, and $R O A=$ return on assets, calculated by Compustat item (\#170-\#192)/lagged total assets. 
Table 4. Regression Results -FIN 48 Adjustment To Beginning 2007 Retained Earnings: Firms With Non-Big Four Auditors

Model:

FIN48ADJ $_{i}=\alpha_{0}+\alpha_{1}$ TAGG $_{i}+\alpha_{2}$ SMOOTHER $_{i}+\alpha_{3}$ TAGG $^{*}$ SMOOTHER $_{i}+\alpha_{4}$ ROA $+\varepsilon_{i}$

DA Estimated Using the method of

Dechow et al. (1995)

No. of Firms:

Model F-value:

Adj. R square:

\begin{tabular}{c|c|c} 
Adj. R square: & 0.67 & 0.73 \\
\hline Variable & \multicolumn{2}{|c}{ Coefficient Estimate (t value) } \\
\hline \hline Constant & $-0.06(-15.73)^{* *}$ & $-0.03(-11.68)^{* *}$ \\
\hline Earnings Managers & $7.04(28.85)^{* *}$ & $5.13(32.98)^{* *}$ \\
\hline Tax Aggressive & $0.00(1.35)$ & $0.00(0.82)$ \\
\hline $\begin{array}{c}\text { Tax Aggressive and Earnings } \\
\text { Manager }\end{array}$ & $-0.02(-4.39)^{* *}$ & $-0.01(-3.66)^{* *}$ \\
\hline ROA & $-0.01(-3.82)^{* *}$ & $-0.01(-4.43)^{* *}$ \\
\hline
\end{tabular}

** significant at the 0.01 level

Notes: FIN48ADJ $=\$$ restatement of beginning 2007 retained earnings, manually taken from firms' 2007

Form 10-Q for the first quarter of 2007. This amount is then divided by lagged total assets, to control for size effects across firms;

$T A G G=$ tax aggressiveness, where $\mathrm{TAGG}=1$ if 1 - cash effective tax rate is greater than the sample median, and 0 otherwise, as determined over prior 6 years;

SMOOTHER $=$ degree to which firm uses discretionary accruals, where SMOOTHER=1 if (the absolute value of) discretionary accruals are greater than the sample median, and 0 , otherwise, as determined over prior 6 years, and $R O A=$ return on assets, calculated by Compustat item (\#170-\#192) /lagged total assets.

Table 5. Discretionary Accruals Before and After FIN 48

Model:

$D A i, t=\delta 0+$ YRdummies $+\varepsilon i, t$

DA Estimated Using the method of Dechow et al. DA Estimated Using the method of 1995

Kothari et al. 2005

Sample Observations:

17,376

17,381

Model F-value:

$22.83 * *$

$11.13 * *$

Adj. $R^{2}$ :

0.01

0.01

\begin{tabular}{l|l|l}
\hline Variable & Coefficient Estimate (t value) & \\
\hline \hline Constant) & $0.07(49.10)^{* *}$ & $0.06(47.86)^{* *}$ \\
\hline 2002 dummy & $-0.01(-4.96)^{* *}$ & $-0.01(-3.80)^{* *}$ \\
\hline 2003 dummy & $-0.02(-8.39)^{* *}$ & $-0.01(-6.99)^{* *}$ \\
\hline 2004 dummy & $-0.01(-7.11)^{* *}$ & $-0.01(-5.60)^{* *}$ \\
\hline 2005 dummy & $-0.02(-8.94)^{* *}$ & $-0.01(-7.28)^{* *}$ \\
\hline 2006 dummy & $-0.02(-7.06)^{* *}$ & $-0.01(-6.03)^{* *}$ \\
\hline 2007 dummy & $-0.03(-8.89)^{* *}$ & $-0.02(-8.18)^{* *}$ \\
\hline
\end{tabular}

** significant at the 0.01 level

Notes:(1) DA Estimated Using the method of Dechow et al. 1995: TA $\mathrm{it}_{\mathrm{it}}=\beta_{0}+\beta_{1} / \mathrm{ASSETS}_{\mathrm{it}-1}+\beta_{2} \Delta\left(\mathrm{SALES}_{\mathrm{it}}-\mathrm{AR}_{\mathrm{it}}\right)+\beta_{3} \mathrm{PPE}_{\mathrm{it}}+\varepsilon_{\mathrm{it}}$, where:

$T A_{i t}=$ the total accruals in fiscal year $\mathrm{t}$ obtained by subtracting operating cash flows from net income before extraordinary items and discontinued operations, deflated by the beginning-of-year total

assets; $\operatorname{ASSETS}_{i t-1}=$ the total assets at the beginning of fiscal year $\mathrm{t}, \triangle\left(S A L E S_{i t}-A R_{i t}\right)=$ the change in sales, adjusted for the change in accounts receivable from fiscal years $\mathrm{t}-1$ to $\mathrm{t}$, deflated by the beginning-of-year total assets, and $P P E_{i i}=$ the gross property, plant and equipment at the end of fiscal year $\mathrm{t}$, deflated by the beginning-of-year total assets.

(2) DA Estimated Using the method of Kothari et al. 2005: TA $\mathrm{it}_{\mathrm{it}}=\beta_{0}+\beta_{1} / \mathrm{ASSETS}_{\mathrm{it}-1}+\beta_{2} \Delta\left(\mathrm{SALES}_{\mathrm{it}}-\mathrm{AR}\right)+\beta_{3} \mathrm{PPE}_{\mathrm{it}}+\beta_{4} \mathrm{ROA}_{\mathrm{it}}+\varepsilon_{\mathrm{it}}$, where: $\mathrm{ROA}_{\mathrm{it}}=$ net income divided by lagged total assets of fiscal year $\mathrm{t}$. 
Table 6. Variance in Effective Tax Rates and Discretionary Accruals Before and After FIN 48

\begin{tabular}{|c|c|c|c|c|c|c|c|c|}
\hline Variable & Data Year & 2001 & 2002 & 2003 & 2004 & 2005 & 2006 & 2007 \\
\hline \multirow{2}{*}{ ETR } & $\begin{array}{l}\text { Variance } \\
\text { (per cent) }\end{array}$ & 2.483 & 7.480 & 5.712 & 3.192 & 2.979 & 15.084 & 9.953 \\
\hline & $\begin{array}{c}\text { F Test of Equality of } \\
\text { Variance }\end{array}$ & 3.012 & 1.309 & 1.790 & 1.071 & 5.063 & 1.516 & \\
\hline \multirow{2}{*}{$\begin{array}{c}\text { Discretionary } \\
\text { Accruals } \\
\text { (Dechow et al.) }\end{array}$} & Variance & 0.158 & 1.398 & 0.114 & 0.824 & 0.316 & 4.126 & 0.005 \\
\hline & $\begin{array}{c}\text { F Test of Equality of } \\
\text { Variance }\end{array}$ & 8.839 & 12.212 & 0.139 & 2.605 & 13.047 & 831.148 & \\
\hline \multirow{2}{*}{$\begin{array}{l}\text { Discretionary } \\
\text { Accruals } \\
\text { (Kothari et al.) }\end{array}$} & Variance & 0.879 & 3.455 & 0.165 & 1.368 & 0.064 & 0.548 & 0.004 \\
\hline & $\begin{array}{c}\text { F Test of Equality of } \\
\text { Variance }\end{array}$ & 3.932 & 20.993 & 8.309 & 21.440 & 8.585 & 135.804 & \\
\hline
\end{tabular}

** Significant at 0.01 level

Notes:(1) ETR: effective tax rate $=$ total tax expense/pretax income $=$ Compustat item \#16/\#170; (2) DA Estimated Using the method of Dechow et al. 1995; (3) DA Estimated Using the method of Kothari et al. 2005; (4) DTE/Total Assets = Deferred tax expense divided by total assets $=$ North America Compustat item \#50/\#6; Global Compustat item \#25/\#89

Table 7. Differences between IFRS and US GAAP

\begin{tabular}{|c|c|c|c|}
\hline No & TOPIC & IFRS & US GAAP \\
\hline 1 & $\begin{array}{l}\text { 'Initial } \\
\text { recognition' } \\
\text { exemption }\end{array}$ & $\begin{array}{l}\text { Deferred tax not recognized for taxable temporary } \\
\text { differences that arise from the initial recognition of an asset } \\
\text { or liability in a transaction that is (a) not a business } \\
\text { combination, and (b)does not affect accounting profit or } \\
\text { taxable profit }\end{array}$ & No exemption \\
\hline 2 & $\begin{array}{l}\text { An intra-group } \\
\text { transfer of assets }\end{array}$ & $\begin{array}{l}\text { Deferred tax is recognized for the difference in tax bases } \\
\text { between jurisdictions as a result of an intra-group transfer } \\
\text { of assets }\end{array}$ & Not recognized \\
\hline 3 & $\begin{array}{l}\text { Exchange gains and } \\
\text { losses }\end{array}$ & $\begin{array}{l}\text { Deferred tax is recognized for exchange gains and losses } \\
\text { related to foreign no-monetary assets and liabilities that are } \\
\text { remeasured into the functional currency using historical } \\
\text { exchange rates or indexing for tax purposes }\end{array}$ & Not recognized \\
\hline 4 & $\begin{array}{l}\text { When it is probable } \\
\text { and will be realized }\end{array}$ & $\begin{array}{l}\text { Deferred tax is recognized if it is probable and will be } \\
\text { realized }\end{array}$ & $\begin{array}{l}\text { All deferred tax assets are recognized and a valuation } \\
\text { allowance is recognized to the extent that it is more } \\
\text { likely than not that the deferred tax assets will not be } \\
\text { realized }\end{array}$ \\
\hline 5 & $\begin{array}{l}\text { Tax rate for } \\
\text { measuring } \\
\text { deferred tax } \\
\text { assets and } \\
\text { liabilities }\end{array}$ & $\begin{array}{l}\text { Use enacted or 'substantively } \\
\text { enacted' tax rate }\end{array}$ & Use enacted tax rate. \\
\hline 6 & $\begin{array}{l}\text { Measuring } \\
\text { deferred tax } \\
\text { assets and } \\
\text { liabilities }\end{array}$ & $\begin{array}{l}\text { Deferred tax is measured based on the expected manner of } \\
\text { settlement(liability) or recovery(asset) }\end{array}$ & $\begin{array}{l}\text { Deferred tax is measured based on an assumption that } \\
\text { the underlying asset(liability) will be recovered(settled) } \\
\text { in a manner consistent with its current use in the } \\
\text { business }\end{array}$ \\
\hline 7 & $\begin{array}{l}\text { Classification } \\
\text { of deferred tax } \\
\text { assets and } \\
\text { liabilities5 }\end{array}$ & Always non-current & $\begin{array}{l}\text { Classification is split between current and non-current } \\
\text { components based on the classification of the underlying } \\
\text { asset or liability, or on the expected reversal of items } \\
\text { not related to an asset or liability. }\end{array}$ \\
\hline 8 & $\begin{array}{l}\text { Changes in deferred } \\
\text { taxes that were } \\
\text { originally charged } \\
\text { or } \\
\text { credited to equity } \\
\text { ('backward } \\
\text { tracing') }\end{array}$ & $\begin{array}{l}\text { The tax effects of items credited or charged directly to } \\
\text { equity during the current year are allocated directly to } \\
\text { equity }\end{array}$ & $\begin{array}{l}\text { The tax effects of items credited or charged directly to } \\
\text { equity during the current year are allocated directly to } \\
\text { equity. However, subsequent changes are recognized in } \\
\text { profit or loss }\end{array}$ \\
\hline 9 & $\begin{array}{l}\text { Shared-base } \\
\text { payment } \\
\text { arrangements }\end{array}$ & $\begin{array}{l}\text { Deferred tax assets recognized in relation to share-based } \\
\text { payment arrangements are adjusted each period to reflect } \\
\text { the amount of tax deduction that the entity would receive if } \\
\text { the award were tax deductible in the current period based } \\
\text { on the current market price of the shares }\end{array}$ & $\begin{array}{l}\text { Recognized in profit or loss without any adjustment for } \\
\text { the entity's current share price until the tax benefit is } \\
\text { realized }\end{array}$ \\
\hline 10 & Offsetting & $\begin{array}{l}\text { Current tax assets and liabilities are offset only when there } \\
\text { is a legally enforceable right of offset, and the entity intends } \\
\text { to apply offset or to settle simultaneously }\end{array}$ & $\begin{array}{l}\text { Current tax assets and liabilities are offset only when } \\
\text { there is a legally enforceable right of offset, however, the } \\
\text { entity need not intend to apply offset or to settle } \\
\text { simultaneously }\end{array}$ \\
\hline
\end{tabular}


Table 8a. EU Effective Tax Rates before IFRS Adoption

\begin{tabular}{ccccccc}
\cline { 2 - 6 } & \multicolumn{2}{c}{2002} & \multicolumn{2}{c}{2003} & \multicolumn{2}{c}{2004} \\
\cline { 2 - 7 } & AVG. ETR & Variance & AVG. ETR & Variance & AVG. ETR & Variance \\
\hline Austria & 0.3072 & 0.0316 & 0.2837 & 0.0288 & 0.2457 & 0.0188 \\
Belgium & 0.2908 & 0.0417 & 0.2685 & 0.0384 & 0.2825 & 0.0287 \\
Cyprus & 0.0503 & $\mathrm{~N} / \mathrm{A}$ & 0.1256 & $\mathrm{~N} / \mathrm{A}$ & 0.1352 & $\mathrm{~N} / \mathrm{A}$ \\
Czech Republic & 0.2487 & 0.0190 & 0.2784 & 0.0476 & 0.2479 & 0.0016 \\
Denmark & 0.2670 & 0.0246 & 0.2600 & 0.0326 & 0.2536 & 0.0250 \\
Estonia & 0.0195 & $\mathrm{~N} / \mathrm{A}$ & 0.0262 & $\mathrm{~N} / \mathrm{A}$ & 0.1507 & $\mathrm{~N} / \mathrm{A}$ \\
Finland & 0.2804 & 0.0262 & 0.3115 & 0.0332 & 0.2537 & 0.0106 \\
France & 0.3070 & 0.0247 & 0.3139 & 0.0240 & 0.2979 & 0.0219 \\
Germany & 0.3112 & 0.0468 & 0.3217 & 0.0443 & 0.3227 & 0.0417 \\
Greece & 0.2955 & 0.0448 & 0.2983 & 0.0450 & 0.2635 & 0.0323 \\
Hungary & 0.1241 & 0.0172 & 0.1374 & 0.0072 & 0.1362 & 0.0140 \\
Ireland & 0.1481 & 0.0197 & 0.1455 & 0.0208 & 0.1319 & 0.0200 \\
Italy & 0.3927 & 0.0409 & 0.4047 & 0.0450 & 0.3840 & 0.0413 \\
Lithuania & 0.1147 & $\mathrm{~N} / \mathrm{A}$ & 0.0775 & $\mathrm{~N} / \mathrm{A}$ & $\mathrm{N} / \mathrm{A}$ & $\mathrm{N} / \mathrm{A}$ \\
Luxembourg & 0.2634 & 0.0466 & 0.2770 & 0.0455 & 0.2513 & 0.0325 \\
Malta & & $\mathrm{N} / \mathrm{A}$ & 0.2543 & $\mathrm{~N} / \mathrm{A}$ & 0.2897 & $\mathrm{~N} / \mathrm{A}$ \\
Netherlands & 0.2652 & 0.0218 & 0.2880 & 0.0325 & 0.2689 & 0.0304 \\
Poland & 0.2902 & 0.0187 & 0.2990 & 0.0185 & 0.2330 & 0.0093 \\
Portugal & 0.2771 & 0.0541 & 0.3173 & 0.0298 & 0.2334 & 0.0169 \\
Romania & 0.0000 & $\mathrm{~N} / \mathrm{A}$ & 0.0000 & $\mathrm{~N} / \mathrm{A}$ & 0.0000 & $\mathrm{~N} / \mathrm{A}$ \\
Slovakia & 0.3873 & 0.0340 & 0.2796 & 0.0036 & 0.2098 & 0.0003 \\
Slovenia & 0.1273 & 0.0071 & 0.0876 & 0.0014 & 0.1506 & 0.0001 \\
Spain & 0.2412 & 0.0145 & 0.2467 & 0.0144 & 0.2655 & 0.0188 \\
Sweden & 0.2189 & 0.0348 & 0.2321 & 0.0356 & 0.2481 & 0.0276 \\
United Kingdom & 0.2211 & 0.0352 & 0.2226 & 0.0343 & 0.2191 & 0.0339 \\
\hline \hline Average & 0.2270 & 0.0302 & 0.2303 & 0.0291 & 0.2281 & 0.0213 \\
\hline
\end{tabular}

Table 8b.EU Effective Tax Rates after IFRS Adoption

\begin{tabular}{ccccccc} 
& \multicolumn{2}{c}{2005} & \multicolumn{2}{c}{2006} & \multicolumn{2}{c}{2007} \\
\cline { 2 - 6 } & AVG.ETR & Variance & AVG.ETR & Variance & AVG. ETR & Variance \\
\hline Austria & 0.2065 & 0.0118 & 0.2238 & 0.0165 & 0.2286 & 0.0069 \\
Belgium & 0.2641 & 0.0200 & 0.2445 & 0.0235 & 0.2559 & 0.0062 \\
Cyprus & 0.1080 & 0.0002 & 0.1148 & 0.0004 & N/A & N/A \\
Czech Republic & 0.2398 & 0.0015 & 0.3008 & 0.0090 & 0.2312 & N/A \\
Denmark & 0.2184 & 0.0164 & 0.2333 & 0.0245 & 0.2089 & 0.0132 \\
Estonia & 0.2001 & N/A & 0.1870 & N/A & 0.1495 & N/A \\
Finland & 0.2456 & 0.0082 & 0.2524 & 0.0104 & 0.2288 & 0.0127 \\
France & 0.2939 & 0.0164 & 0.2937 & 0.0210 & 0.2961 & 0.0121 \\
Germany & 0.2940 & 0.0295 & 0.2691 & 0.0268 & 0.2863 & 0.0187 \\
Greece & 0.3222 & 0.0191 & 0.2854 & 0.0194 & 0.2415 & 0.0041 \\
Hungary & 0.1133 & 0.0061 & 0.1167 & 0.0086 & 0.1426 & 0.0110 \\
Ireland & 0.1210 & 0.0149 & 0.1392 & 0.0246 & 0.1811 & 0.0309 \\
Italy & 0.3570 & 0.0359 & 0.4041 & 0.0427 & 0.3829 & 0.0266 \\
Lithuania & 0.4071 & $\mathrm{~N} / \mathrm{A}$ & 0.1672 & $\mathrm{~N} / \mathrm{A}$ & $\mathrm{N} / \mathrm{A}$ & N/A \\
Luxembourg & 0.2260 & 0.0567 & 0.2030 & 0.0339 & 0.2374 & 0.0429 \\
Malta & 0.3178 & $\mathrm{~N} / \mathrm{A}$ & $\mathrm{N} / \mathrm{A}$ & $\mathrm{N} / \mathrm{A}$ & 0.0677 & N/A \\
Netherlands & 0.2580 & 0.0313 & 0.2313 & 0.0184 & 0.2347 & 0.0087 \\
Poland & 0.2147 & 0.0234 & 0.1892 & 0.0213 & 0.1804 & 0.0002 \\
Portugal & 0.2518 & 0.0349 & 0.1823 & 0.0181 & 0.1398 & 0.0119 \\
Romania & 0.0793 & 0.0126 & 0.1024 & N/A & N/A & N/A \\
Slovakia & 0.2135 & N/A & 0.2017 & N/A & N/A & N/A \\
Slovenia & 0.2275 & 0.0057 & 0.1793 & 0.0029 & 0.0835 & N/A \\
Spain & 0.2596 & 0.0168 & 0.2507 & 0.0192 & 0.2259 & 0.0101 \\
Sweden & 0.2288 & 0.0206 & 0.2296 & 0.0199 & 0.2451 & 0.0123 \\
United Kingdom & 0.1998 & 0.0286 & 0.2031 & 0.0273 & 0.2290 & 0.0214 \\
\hline \hline Average & 0.2347 & 0.0196 & 0.2169 & 0.0194 & 0.2132 & 0.0147 \\
\hline
\end{tabular}




\begin{tabular}{|c|c|}
\hline$\frac{\text { Before FIN } 48}{\text { Loss-contingency approach of FAS } 5}$ & $\begin{array}{l}\text { After FIN } 48 \\
\text { Gain-contingency approach \& } \\
\text { 2-step process }\end{array}$ \\
\hline (1) Record tax benefit; & $\begin{array}{l}\text { (1) Recognition Test - more likely than not (MLTN) threshold test: } \\
\text { (a) if not satisfied, the firm cannot record any tax benefit; } \\
\text { (b) When the tax benefit meets the MLTN threshold test- } \rightarrow \\
\text { measurement of the tax benefit: }\end{array}$ \\
\hline $\begin{array}{l}\text { (2) Determine if the likelihood of losing that benefit was } \\
\text { probable, then record: } \\
\text { (Dr) Tax Expense xx /(Cr) Income Tax Payable xx } \\
\text { reasonably possible: only disclosure } \\
\text { was required. }\end{array}$ & $\begin{array}{l}\text { (2) Measurement Test: measured at the largest amount of benefit that } \\
\text { is greater than } 50 \% \text { likely of being realized upon ultimate settlement. } \\
\qquad \begin{array}{l}\text { tax benefits } \\
\text { tax returns benefits }\end{array} \\
\text { "differences" between } 2 \text { tax positions above: the process } \\
\text { (increase) }\end{array}$ \\
\hline
\end{tabular}

Figure 1. Accounting for Uncertainty in Income Taxes 